\title{
Analysis and Comparison of Energy Efficiency Code Requirements for Buildings: A Morocco-Spain Case Study
}

\author{
Ikram Merini ${ }^{1,+}$, Angel Molina-García ${ }^{2, *,+}$ [, M. Socorro García-Cascales ${ }^{1,+}+\mathbb{0}$, \\ Mustapha Mahdaoui ${ }^{3,+}$ (D) and Mohamed Ahachad ${ }^{3,+}$ \\ 1 Department of Electronics, Comp. Architecture and Project Engineering, \\ Universidad Politécnica de Cartagena, 30202 Cartagena, Spain; ikramalmerini@hotmail.com (I.M.); \\ socorro.garcia@upct.es (M.S.G.-C.) \\ 2 Department of Automatics, Electrical Eng. and Electronic Technology, Universidad Politécnica de Cartagena, \\ 30202 Cartagena, Spain \\ 3 Faculty of Sciences and Techniques, Abdelmalek Essaadi University, B.P. 416 Tangier, Morocco; \\ mustapha_mahdaoui@yahoo.fr (M.M.); ahachad_med@yahoo.fr (M.A.) \\ * Correspondence: angel.molina@upct.es; Tel.: +34-968-32-5462 \\ + These authors contributed equally to this work.
}

Received: 26 September 2020; Accepted: 10 November 2020; Published: 16 November 2020

\begin{abstract}
The trend in energy consumption, with a particular focus on heating and cooling demand, is an issue that is relevant to the promotion of new energy policies and more efficient energy systems. Moreover, heating and cooling energy demand is expected to rise in the next several decades, mainly due to climate change as well as increasing incomes in developing countries. In this context, the building sector is currently a relevant energy-intensive economic sector in Morocco; it accounts for 33\% of the country's total energy demand (as the sector with the second highest energy demand, after the transport sector), with the residential sector accounting for $25 \%$ and the tertiary sector accounting for $8 \%$. Aiming to reduce energy dependence and promote sustainable development, the Moroccan government recently issued a comprehensive plan to increase the share of renewables and improve energy efficiency. This strategy includes novel thermal building regulations promoted by the Moroccan Agency for Energy Efficiency. This paper analyzes the thermal behavior and heating-cooling energy demand of a residential building located in Tangier (Morocco) as a case example, based on the country's new thermal regulations and considering specific climatological conditions. A comparison with common Moroccan residential buildings as well as with those in nearby countries with similar meteorological conditions but significant differences in terms of energy demand regulation and requirements, such as Spain, is also included. Simulations were carried out using the DesingBuilder and EnergyPlus Software packages. According to the results, the last building thermal regulation requirements in Morocco need to be revised and extended in order to achieve the energy efficiency objectives established by the Moroccan government for 2030.
\end{abstract}

Keywords: energy efficiency in buildings; energy policies; energy simulation

\section{Introduction}

The relevant increase in energy demand and its effects on the environment have led countries to promote actions and programs in order to mitigate these negative environmental, economic and energy dependence effects. These countries have also developed national legislative frameworks to regulate efficient and renewable energy scenarios according to the different sectors and their energy requirements. Among the different sectors, end-use energy consumption in buildings globally 
increased from 2820 millions of tons of oil equivalent (Mtoe) in 2010 to 3060 Mtoe in 2018 [1]. Buildings' energy consumption accounts for approximately $40 \%$ of global energy consumption, mainly demanded by heating, ventilation and air conditioning (HVAC) systems [2]. However, the fossil fuel proportion only decreased slightly from $38 \%$ in 2010 to $36 \%$ in 2018. Indeed, oil use still accounts for $63 \%$ of Morocco's residential energy consumption. This percentage is exceptionally high in comparison with that of most IEA countries, with an IEA average of $13 \%$ oil use [3]. Under this scenario, some authors also highlight the importance of the energy poverty concept in current European countries, mainly due to poor energy performance of buildings and high energy costs [4]. Kephalopoulos et al. [5] affirmed that energy poverty is a common issue in social housing, mainly in Southern European countries, due to the low income level of their inhabitants. These countries have more favorable climatic conditions, but commonly present poorer building insulation, less efficient thermal equipment, and, with regard to the average user, a lack of energy-efficient habits. Added to this is the fact that around 50 million Europeans live in energy poverty conditions, with inefficient homes and, consequently, high energy bills to maintain minimum comfort levels [6]. This high energy dependence and poverty condition situations can be also found in areas near Europe, such as Morocco [7]. Indeed, the European Union (EU) addressed a relevant review of its Mediterranean neighborhood policy to improve its efficiency and reinforce its ambition and financing. The EU institutional relationships with the Middle East and North African countries (MENA) are currently defined by the European Neighbourhood Policy (ENP). Among the MENA countries, Turkey and Morocco are currently the countries with deeper relations with the EU [8]. As far as the Human Development Index is concerned, Morocco's Human Development Index (HDI) in 2014 was 0.628, which classified the country in the medium human development category and ranked it 126th (shared with Namibia) out of 188 countries [9]. The gross domestic product (GDP) per capita was 3.190 in 2014 (in US\$). Currently, Morocco receives an estimated score of 0.50 on the World Bank's HDI. The country is ranked 98th out of 157 countries, with a lower $\mathrm{HCI}$ score than the MENA average region but a higher score than the average for other countries in its income classification [10,11]. The Sustainable Development Goals (SDGs) included in the 2030 Agenda propose a commitment to promote sustainable consumption and reduce inequalities within and among countries [12]. In [13], the incorporation of inclusive and sustainable industrialization, as well as infrastructure, into the SDGs is a significant achievement for countries of the global South. Nevertheless, and by considering previous aspects, it can be affirmed that Morocco is totally dependent on energy source imports, mainly fossil fuels, with significant repercussions in terms of national energy security and the economy [14]. To mitigate this energy dependence, Morocco has decreased its fossil fuel imports from 95\% during the last decades to lower percentages in 2017: oil accounted for 62\% of the total primary energy supply, and coal and natural gas accounted for $22 \%$ and $5 \%$, respectively. In 2017, the global imported primary energy mounted to 69.5 billion dirhams (7.3 billion dollars) [15]. In October 2019, the value of primary imported energy decreased $6.6 \%$ compared with the same period in 2018 [16]. Figure 1 shows this evolution of the energy dependence (2018-2019) in millions of dirhams (MDHS); 1 million dirhams is equivalent to almost 100,000 euro. Energy consumption in buildings in Morocco represents $33.6 \%$ of the total, with the residential sector accounting for $25.4 \%$ and the tertiary sector accounting for $8.2 \%$. The building sector has the second highest energy consuming sector in Morocco, after the transport sector, which accounts for 38\% [17] (see Figure 2).

With regard to Spain, the global energy consumption in 2017 accounted for $84.9 \mathrm{Mtep}, 2.9 \%$ higher than the 2016 global demand. The transport sector, with $43 \%$ of total consumption, maintained its high relevance, followed by the industry sector, with $24 \%$ of demand. Nevertheless, the industry sector is progressively losing importance in terms of both demand and contribution to the national gross domestic product (GDP), in correspondence with the tertiarization of the economy and reinforced in the context of the current crisis. The Spanish residential and tertiary sectors account for $30 \%$ of the global consumption, of which 57.2\% corresponds to house demand [18]; see Figure 3. Both countries present similar meteorological data and climate conditions. Actually, some analysis and studies comparing both locations can be found in the specific literature. For example, Merrouini et al. [19] 
discussed the possibility of large-scale photovoltaic (PV) power plant installation in the Eastern region of Morocco, and compared their results to a PV installation located in southern Spain. Touli et al. [20] analyzed green hydrogen production under different Moroccan climate conditions and from different solar energy systems, benchmarking these results against the ones from Almeria (Spain). In fact, Ezzine et al. [21] affirmed that Morocco is basicly characterized by a Mediterranean climate with hot and dry summers and mild and relatively wet winters. Under these climate and meteorological similarities, the relevant policy discrepancies in terms of thermal building regulation and energy efficiency must be noted. Moreover, there is a lack of contributions to compare thermal building design differences between both continents under similar climate zones and according to the most recent energy efficiency policy novelties. With this aim, in this paper, we describe and compare both Spanish and Moroccan thermal building and energy efficiency regulations, providing results from a reference building case example located invTangier (Morocco) and aiming to meet the corresponding national energy requirements.

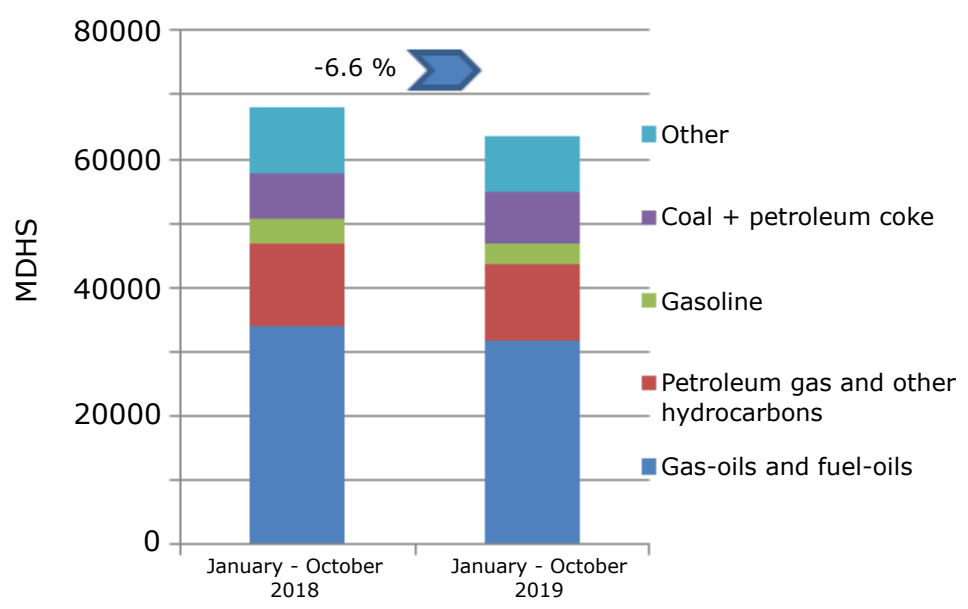

Figure 1. Evolution of the energy dependence imports in Morocco (2018-2019) [16].

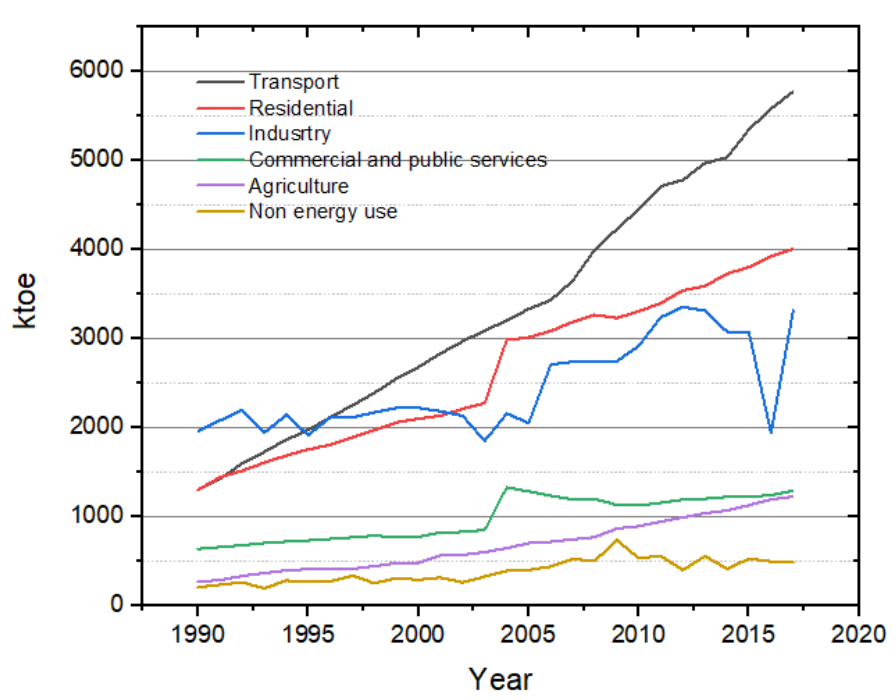

Figure 2. Energy consumption evolution in Morocco by sectors (1990-2020) [17]. 


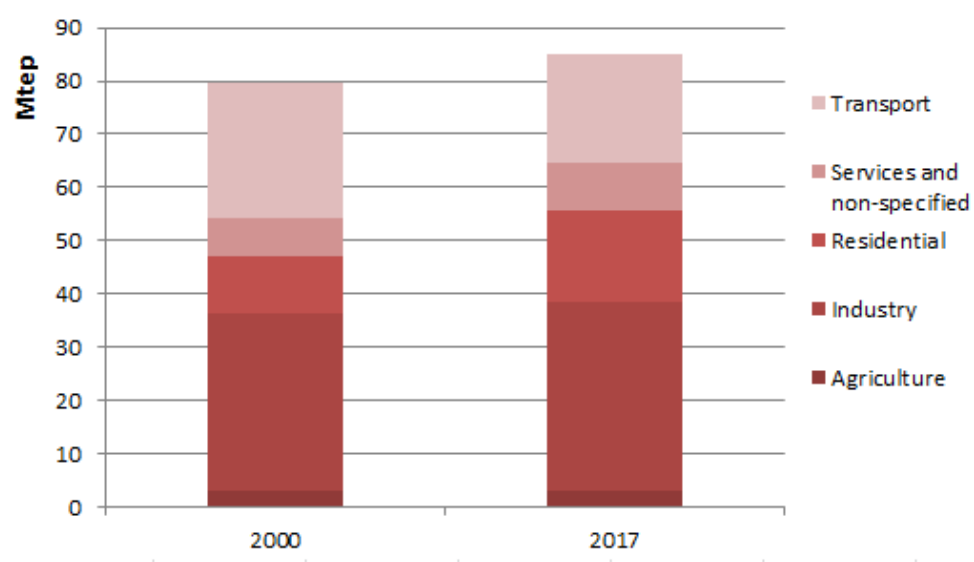

Figure 3. Final energy consumption by sectors in Spain: 2000-2017 comparison [18].

The rest of the paper is structured as follows. In Section 2, the legislative frameworks and energy policies for Spain and Morocco are described. In Section 3, detailed revisions of both climate zones are given and the methodology proposed to compare the reference buildings is described. In Section 4, the results in terms of energy demand and indoor/outdoor temperature evolution data are provided. Discussion of the results can be found in Section 5. Finally, the conclusions are given in Section 6.

\section{Legislative Framework and Energy Policy}

\subsection{Morocco}

Currently, Morocco is involved in important economic and social development, transitioning into green development [22]. In 2009, Morocco adopted a National Energy Strategy (NES) with aims to improve the security of supply and availability of energy and increase the general accessibility of energy at reasonable prices [23]. To achieve these objectives, a variety of energy policies have been promoted; these policies have mainly focused on the diversification of sources, the development of the national potential in energy resources (in particular, renewables), the promotion of energy efficiency and a favorable integration in the regional energy system. In addition to this energy strategy, the Moroccan government has promoted an energy efficiency policy focused on clarifying the relationships between administrations and operators. The aims of this energy efficiency policy are to provide an institutionalized public management system for energy efficiency issues and a suitable legislative and regulatory framework, as well as to promote norms and standards. In this way, the government of Morocco also issued Law 47-09 relative to energy efficiency. In Article 3 of the legislation, fulfillment of the requirements corresponding to urban planning, the "general building regulations", is mandatory, setting the rules for the building energy performance. This regulation focuses on guaranteeing a suitable building energy balance for each climatic zone, considering the building's lighting, orientation, insulation and thermal flows, as well as any renewable energy contribution in line with the building performance level improvement. Such new requirements are applicable to both new buildings and renovations. In 2014, Decree n. 2-13-874 was issued, developing the set of thermal construction regulations (Réglementation Thermique de Construction, RTCM) in Morocco and establishing them as mandatory in November 2015. This decree established a set of minimum thermal technical specifications of the building envelope, such as exterior walls, roofs or windows. In addition, annual maximum thermal requirements for both cooling and heating energy demand are fixed depending on the climate zoning [24,25]. According to Morocco's 2015 energy strategy, goasl of $12 \%$ energy savings for 2020 and $20 \%$ energy savings for 2030 were set [26]. Table 1 shows the different standards and policies related to the energy efficiency in buildings from the Moroccan energy regulations. With regard to the energy labeling of electrical products and household 
appliances, the current Moroccan standards are compulsory for photovoltaic products and solar thermal installations [27].

Table 1. Energy regulations in the building sector (Morocco).

\begin{tabular}{lcc}
\hline Policy & Year & Status \\
\hline Decree n. 927-20 on the compulsory application of Moroccan standards. & 2020 & In force \\
Photovoltaic products and solar thermal installations & 2019 & In force \\
Decree n. 2-17-746 on Mandatory energy audits and energy audit organisations & 2019 & In force \\
Energy efficiency program for public buildings & 2018 In force \\
MEPS for Air Conditioners & 2016 In force \\
Nationally Determined Contributions (NDC) & 2015 In force \\
MorSEFE & 2014 In force \\
Decree n. 2-13-874 on Thermal regulation of buildings & 2010 In force \\
Moroccan Standard NM 14.2.300 & \\
\hline
\end{tabular}

\subsection{European Union and Spain}

In the European Union (EU), the energy efficiency of buildings was initially regulated with Directive 2002/91/EC. This directive promoted the energy performance of buildings (EPBD) improvement within the community. With this aim, local conditions, indoor climate requirements, outdoor climatic and cost-effectiveness are considered and analyzed, establishing minimum energy efficiency requirements for new and renovated buildings with a total useful area larger than $1000 \mathrm{~m}^{2}$. The energy efficiency certificate was introduced with this directive [28,29]. In October 2014, the European Council approved the EU's framework for action on energy and climate until 2030. In terms of energy efficiency, an indicative objective is set of at least $27 \%$ in 2030 regarding future energy consumption forecasts based on such current criteria [30]. The need to continue advancing in the achievement of a safe, competitive and environmentally sustainable energy model and, more specifically, to persevere in European decarbonization, has led to the revision and modification of different directives. Among these directives, the authors point out the publication of 2010/31/EU on energy efficiency of buildings, an updated version of the previous EPBD, including the concept of a building with almost zero consumption; and the 2012/27/EU related to energy efficiency, recently updated through EU-Directive 2018/844, which highlights the prioritization of energy efficiency versus renewables, the establishment of a long-term building stock renovation strategy aimed at decarbonization by 2050, and the introduction of an indicator for smart building applications in terms of user need estimation and operational energy consumption information [31].

From these previous directives, Spanish advances have promoted the transposition of such European regulations through a number of national regulatory provisions increasing different regulations and requirements, such as the Spanish Technical Building Code (Royal Decree 732/2019), the Regulation on Building Heating Installations (Royal Decree 238/2013) and the energy certification of buildings (Royal Decree 235/2013). In addition, RD 314/2006, which approves the Technical Building Code of Spain, includes the considerations of Directive 2002/91/CE, relative to the energy efficiency of buildings, reflected in the Basic Energy Saving Document alongside different versions depending on the changes in their corresponding directives [32]. The latest version of the Spanish Technical Building Code was published through RD 732/2019, including the considerations of the European Directive 2018/844. In addition, energy saving and thermal insulation are incorporated as fundamental pillars of energy efficiency in a building. Both the technical building code (Código Técnico de la Edificación, CTE) and the regulation of thermal installations in buildings (Reglamento de Instalaciones Térmicas en los Edificios, RITE) were approved by RD 1027/2007 [33]. Table 2 compares Spanish and Moroccan energy efficiency legislation in terms of penalties, incentives and criteria. Additionally, Table 3 summarizes variables under consideration for national rules. As can be seen, the Spanish energy efficiency legislation is more strict in terms of variables and parameters under consideration, including 
renewable integration (PV installations) and lighting efficiency which are neglected in the current Moroccan regulation.

Table 2. Spanish and Moroccan legislation on energy efficiency: comparison.

\begin{tabular}{ccccccc}
\hline Country & Regulation & \multicolumn{2}{c}{$\begin{array}{c}\text { Energy Efficiency Criteria } \\
\text { Design }\end{array}$} & Construction & Penalties & Incentives \\
\hline Spain & Technical Building Code (2019) & Yes & Yes & Yes & Yes \\
\hline Morocco & Technical Building Code (2015) & Yes & No & No & No \\
\hline
\end{tabular}

Table 3. Spanish and Moroccan legislation on energy efficiency: variables under consideration.

\begin{tabular}{ccccccccc}
\hline Country & Heating/Cooling & $\begin{array}{c}\text { Construction } \\
\text { Methodology Details }\end{array}$ & $\begin{array}{c}\text { Wall-Ceiling } \\
\text { Insulation }\end{array}$ & $\begin{array}{c}\text { Sealing \& } \\
\text { Ventilation }\end{array}$ & $\begin{array}{c}\text { Lighting } \\
\text { Efficiency }\end{array}$ & $\begin{array}{c}\text { Window U-Value } \\
\text { and Solar Factor }\end{array}$ & $\begin{array}{c}\text { SHW } \\
\text { Integration }\end{array}$ \\
\hline Spain & Yes & Yes & Yes & Yes & Yes & Yes & Yes & Yes \\
\hline Morocco & No & Yes & Yes & No & No & Yes & No & No \\
\hline
\end{tabular}

\section{Materials and Methods}

\subsection{Preliminaries: Climate Zones}

Climate zoning is a key factor in many energy efficiency programs and policies in buildings. These mandatory values or recommendations are key-elements of most building energy efficiency programs [34]. Xiong et al. [35] affirmed that smaller and more homogeneous climate zones may help building designers and policymakers to maximize building energy efficiency and, in parallel, improv the indoor thermal environment. As was discussed in Section 2.1, the climatic zones were determined in the Moroccan case according to the national RTCM. The Moroccan territory was then subdivided based on the 37 meteorological stations over 10 years for the period of 1999-2008. Different simulations of some annual thermal needs for heating and cooling energy demands were carried out on seven case example buildings chosen in accordance to the corresponding ministries. The TRNSYS software package-with hourly annual climatic files—was subsequently used for such simulation purposes in twelve representative Moroccan cities. Six different climatic zones were identified, based on such daily heating and/or cooling energy consumptions. Note that these final climatic zones are confined according to administrative limits [36]. Figure 4 shows the geographic characterization of these areas [37]. In this way, Walsh et al. [38] reviewed climatic zoning methodologies for building energy efficiency programs adopted by 54 countries and, despite the fact that there are different methods to define climatic zones, such as the degree-day method, cluster analysis method, energy simulation of buildings and administrative division, they concluded that around $80 \%$ of such countries only used three variables/techniques/parameters to define their corresponding climatic zoning. This simplicity clearly comes at the cost of ignoring several aspects of climate and building energy performance, which must be included in future revisions and are currently neglected. In addition, Köppen-Geiger classification proposed by Kottek et al. [39], and based on precipitation and temperature, estimated six classes for Morocco: BSk (cold semi-arid (steppe) climate), Csa (hot-summer Mediterranean climate), BWh (hot deserts climate), BWk (cold desert climate), Csb (warm-summer Mediterranean climate) and BSh (hot semi-arid (steppe) climate). The spatial coverages of these classes differ from the climate zoning shown in Figure 4.

With regard to the Spanish case, a reference climate is specified to establish the climatic zones. Consequently, different external stresses are defined in terms of temperature and solar radiation [40]. The Spanish basic energy saving requirements (Documento Básico Ahorro de Energía, DB-HE) establish the climatic zoning for limiting energy demand to a total of 17 zones, 12 of them in peninsular areas. Winter climate severity (WCS) and summer climate severity (SCS) are defined based on the climatic severity of winter and summer for certain Spanish localities. These parameters depend on average degree days, based on $20{ }^{\circ} \mathrm{C}$ in summer (from June to September) or winter (from December to 
February), respectively, calculated hourly and then divided by 24 . The DB-HE defines the climatic severity as the ratio between the energy demanded by a building in a locality and the corresponding amount of energy to the same building in a reference locality, which, according to these regulations, considers Madrid as a referential locality with climatic severity unit. Therefore, the identification of each climatic zone reflects the WCS letter, from A to E, and the number according to the SCS, from 1 to 4. Buildings listed in the Spanish energy performance certificate database belong to the $\mathrm{C} 2$ climate zone $(74.0 \%)$, the B3 climate zone (10.7\%) or the D3 zone (3.4\%). Both general or simplified procedures are able to obtain an energy performance certificate, recognized by the Spanish Ministry according to the Royal Decree 235/2013 (Spain, 2013). Most of the energy performance certificates included in the database were obtained using CE3X software (99.3\%). Only $0.7 \%$ certificates were based on other verified software tool results [41]. The climatic zones of Spain are distributed according to Table 4; a total of 12 different zones were obtained in this country by combining WCS and SCS [42].

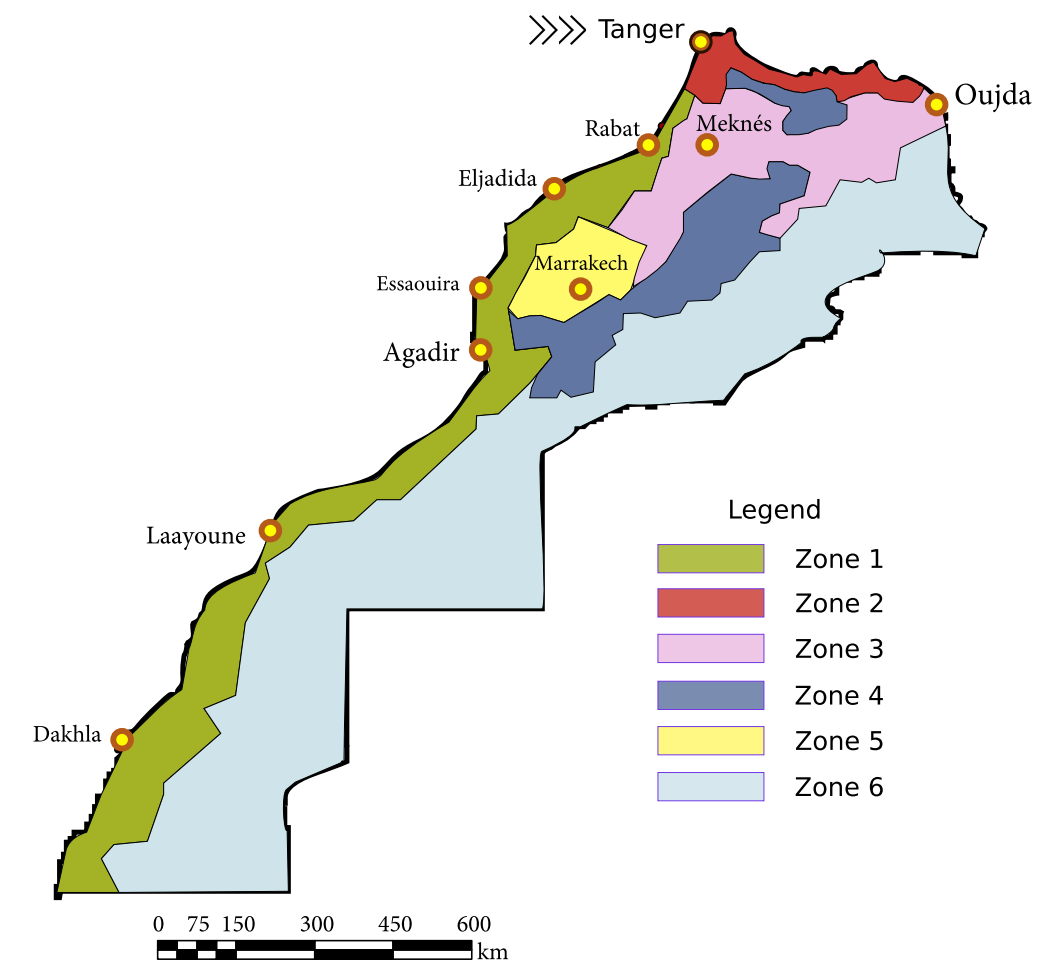

Figure 4. Climatic zones for current thermal building regulation in Morocco (Adapted from [25]).

Table 4. Spanish climatic zones based on winter and summer climate severity [42].

\begin{tabular}{lclc}
\hline Winter Climate Severity (WCS) & \multicolumn{2}{l}{ Summer } & Climate Severity (SCS) \\
\hline A & WCS $\leq 0.30$ & 1 & SCS $\leq 0.60$ \\
B & $0.30<$ WCS $\leq 0.60$ & 2 & $0.60<$ SCS $\leq 0.90$ \\
C & $0.60<$ WCS $\leq 0.95$ & 3 & $0.90<$ SCS $\leq 1.25$ \\
D & $0.95<$ WCS $\leq 1.30$ & 4 & SCS $>1.25$ \\
E & WCS $>1.30$ & & \\
\hline
\end{tabular}

\subsection{Methodology}

The proposed methodology aims to compare a traditional reference residential building located in Tangier (Morocco) in terms of thermal behavior and cooling/heating energy demand according to the current Spanish and Moroccan legislations. This residential building was thus initially designed following the traditional constructive materials in Morocco, and subsequently adapted in line with the new Moroccan thermal regulations described in Section 2.1. The initial design was also compared to the Spanish legislation as an attempt to meet such requirements in terms of maximum energy demand consumption. Therefore, the estimation of annual energy needs of the reference building 
(in $\mathrm{kWh} / \mathrm{m}^{2}$. year) under the different scenarios was proposed and evaluated. Figure 5 shows the general overview of the proposed methodology and the software packages used by the authors, identifying the simulations cases: (i) Scenario 1: reference residential building designed from traditional Moroccan constructive materials; (ii) Scenario 2: reference residential building adapted to the new Moroccan legislation; (iii) Scenario 3: reference residential building adapted to the Spanish annual energy demand requirements.

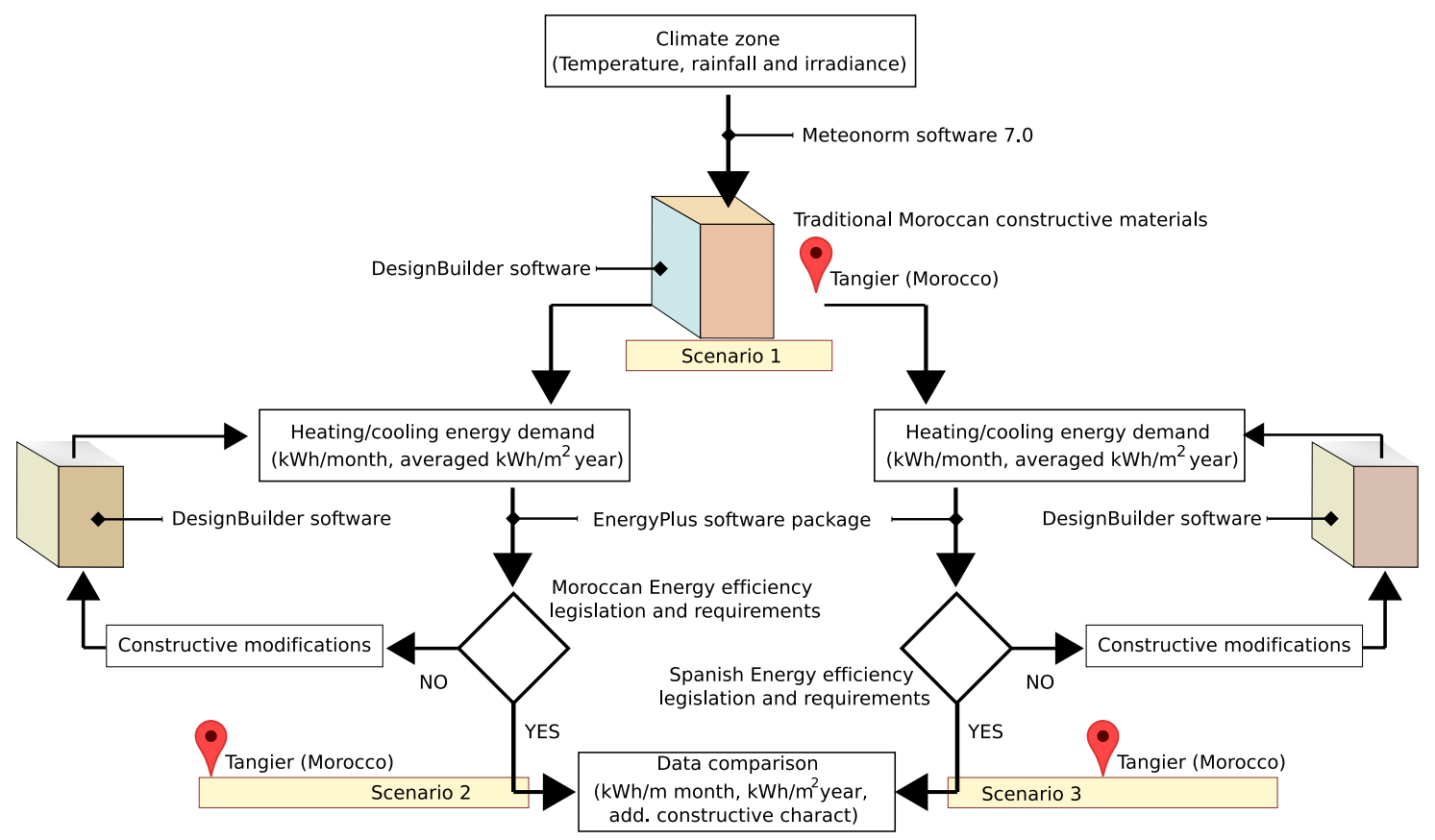

Figure 5. Methodology general description.

A comparison to nearby countries was justified due to the similar meteorological conditions between both regions. In fact, and according to the climatic zones presented in Section 3.1, Tangier (Morocco, climate zone Z2) has meteorological conditions similar to those of the Spanish climatic zone A3-for example, the city of Algeciras (Spain). Figure 6 compares such Mediterranean areas by considering annual meteorological data. Outdoor temperature data also include monthly extremes and interquartile ranges. According to the proposed methodology, meteorological data for two locations-Tangier (Morocco) and Algeciras (Spain)—were obtained through the Meteonorm software 7.0 (Meteotest AG, Fabrikstrasse 14, 3012 Bern, Schweiz) [43] to compare both locations [44], in line with the climate zone definition methodology proposed by Walsh et al. in [45]. This software package was widely used to generate averaged meteorological data, such as incident solar irradiation and ambient temperature. A recent example focused on different Moroccan climate zones-Ben Guerir, Agadir and Tangier-can be found in [46]. 


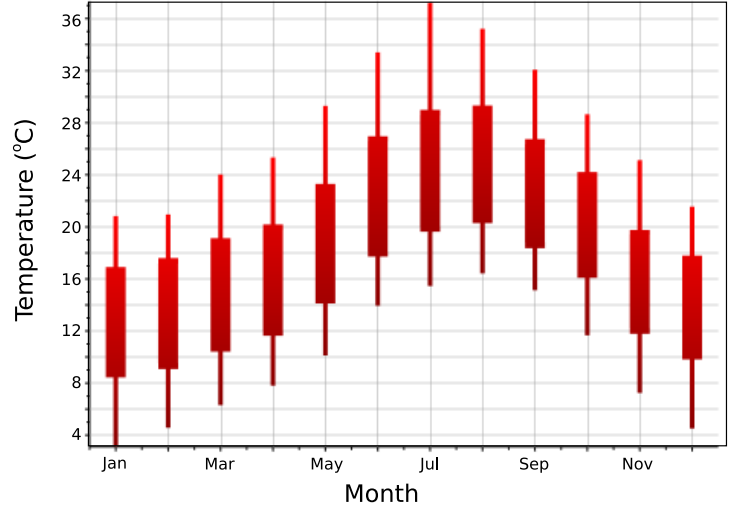

(a) Annual temperature evolution (Tangier).

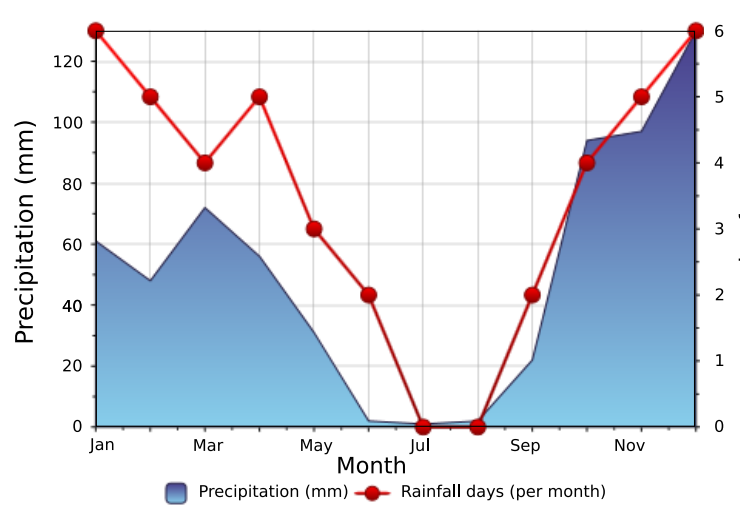

(c) Annual precipitation evolution (Tangier).

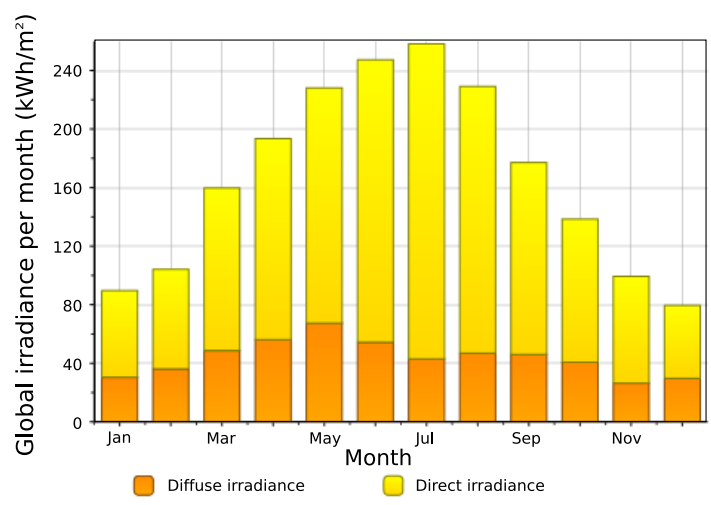

(e) Annual global irradiance evolution (Tangier).

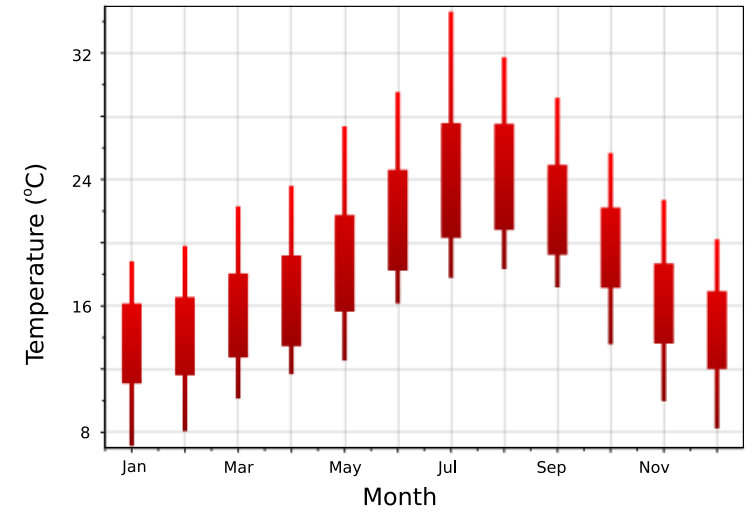

(b) Annual temperature evolution (Algeciras).

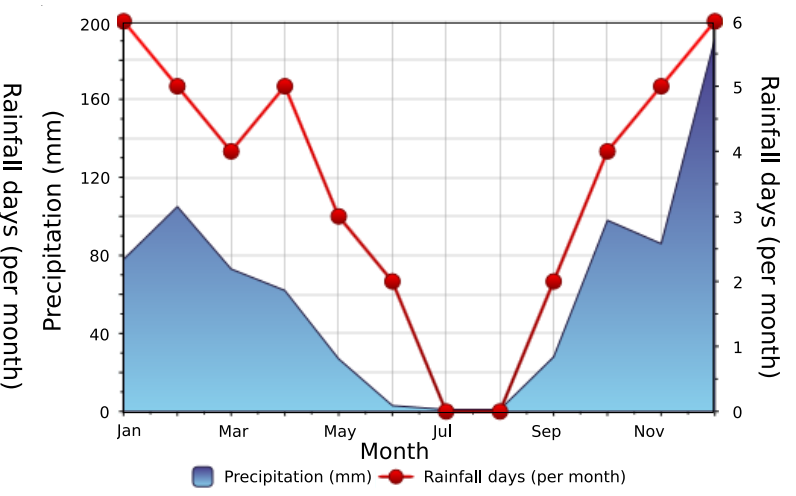

(d) Annual precipitation evolution (Algeciras).

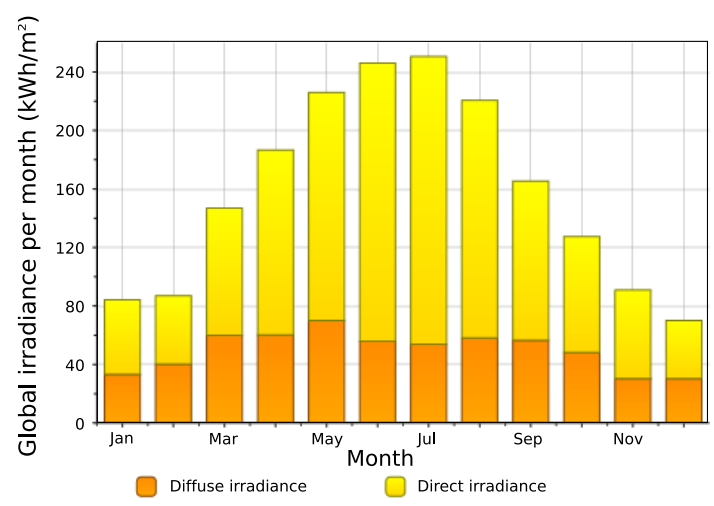

(f) Annual global irradiance evolution (Algeciras).

Figure 6. Meteorological data comparison: Tangier (climate zone Z2, Morocco) vs. Algeciras (climate zone A3, Spain).

As can be seen in Figure 5, we selected the DesignBuilder software package for building modeling and analysis; we also used the EnergyPlus software package for simulation purposes [47]. This software package is widely used as a simulation tool for energy optimization of buildings [48]. In dynamic energy simulations (SED), unlike dynamic thermal simulations (STD) exclusively focused on the envelope, DesignBuilder software is based on the building information modeling (BIM) concept, allowing a coupled simulation of the building and HVAC systems, as well as natural and artificial lighting; further information can be found in [49]. Nevertheless, there are other simulation tools 
also available for these purposes, such as Climawin, Pleiades+COMFEITE, TRNSYS, Tas, Virtual Environment, and ArchiWIZARD. The main expressions of the mathematical thermal model are based on heat transfer balances [50]. For the outdoor wall surface,

$$
q_{\text {solr }}^{\prime \prime}+q_{L W R}^{\prime \prime}+q_{c o n v}^{\prime \prime}-q_{k_{o}}^{\prime \prime}=0,
$$

where $q_{s o l r}^{\prime \prime}$ is the direct and diffuse solar (short wavelength) radiation heat flux, $q_{L W R}^{\prime \prime}$ is the net long-wave (thermal) radiation flux exchange with the air and surroundings, $q_{c o n v}^{\prime \prime}$ is the convective flux exchange with outdoor air and $q_{k_{o}}^{\prime \prime}$ is the conduction heat flux into the outdoor wall. The indoor heat transfer balance is

$$
q_{L W X}^{\prime \prime}+q_{S W}^{\prime \prime}+q_{L W S}^{\prime \prime}+q_{k_{i}}^{\prime \prime}+q_{s o l}^{\prime \prime}+q_{c o n v}^{\prime \prime}=0,
$$

where $q_{L W X}^{\prime \prime}$ is the net long-wave (thermal) radiantion exchange flux among the indoor surfaces, $q_{S W}^{\prime \prime}$ is the net short-wave radiation flux to the surfaces from lights, $q_{L W X}^{\prime \prime}$ is the radiation flux from equipment in zone, $q_{k_{i}}^{\prime \prime}$ is the conduction flux through the indoor wall, $q_{s o l}^{\prime \prime}$ is the solar radiation flux absorbed by the surfaces, and $q_{c o n v}^{\prime \prime}$ is the convective heat flux to indoor air, which is determined using the following heat transfer coefficients,

$$
q_{\text {conv }}^{\prime \prime}=h_{c} \cdot A \cdot\left(T_{s}-T_{a}\right),
$$

where $T_{S}$ is the averaged surface temperature, $T_{a}$ is the averaged indoor air temperature, $A$ the global surface area, and $h_{c}$ are the convection coefficients. These indoor and outdoor convection coefficients $\left(h_{c}\right)$ can be estimated according to different models. Indeed, EnergyPlus provides a wide selection of different methods for determining such $h_{c}$ values: simple combined, TARP, MoWiTT, DOE-2 or the adaptive convection algorithm [51]. In this study, the simple combined algorithm is selected, using surface roughness and local surface wind speed to calculate the outdoor heat transfer coefficient,

$$
h=D \cdot E \cdot v_{z}+F \cdot v_{z}
$$

where $D, E, F$ are the material roughness coefficients, and $v_{Z}$ is the local wind speed calculated at averaged height of the global outdoor surface. Note that the simple correlation yields a combined convection and radiation heat transfer coefficient. Additionally, sky radiation, ground and air radiation values are also included in the outdoor convection coefficient. Long-term estimations for steady-state models are usually applied for scenario analyses and preliminary building design, excluding the inertia effect or including different correction factors [52].

The annual cooling and heating loads needed for the residential reference building to maintain a temperature within the thermal comfort zone allowed by the Moroccan standard RTCM-between $20^{\circ} \mathrm{C}$ and $26^{\circ} \mathrm{C}$, according to [53] - are calculated with the following equation:

$$
B E C T h=\frac{B E C h+B E R e f}{S T C},
$$

where BECTh is the annual energy demand related to the thermal comfort of a building (in $\mathrm{kWh} / \mathrm{m}^{2}$. year), $B E C h$ is the annual heating energy demand $(\mathrm{kWh} /$ year) calculated during the winter period, assuming a base indoor temperature Tch $=20^{\circ} \mathrm{C}, B E R e f$ is the annual cooling energy demand $\left(\mathrm{kWh}\right.$ /year) determined during the summer period for a base indoor temperature Tre $f=26^{\circ} \mathrm{C}$ and STC is the conventionally conditioned total useful area $\left(\mathrm{m}^{2}\right)$.

\subsection{Reference Residential Building}

A reference residential building case example was designed. This reference building consisted of a ground floor and two stories, considering typical apartment layouts. The main façade was oriented to the South. The height of each story was $3 \mathrm{~m}$. On the ground floor was the main entrance, an area for retail space and the garage. The ground floor apartment consisted of a living room, a kitchen 
and one bedroom with a total surface area of $83.4 \mathrm{~m}^{2}$. The first and second floors presented similar distributions with three bedrooms and a total surface area of $100 \mathrm{~m}^{2}$ for each floor. Distribution and general overview are depicted in Figure 7. The reference building was found in the Moroccan climate zone Z2; see Figure 4. The urban context was not included in this case example. Nevertheless, and in linewith [54], simulation in an urban context has a negative impact on the thermal energy demand, since higher values of the demand are usually obtained-i.e., an increment in $\mathrm{kWh} / \mathrm{m}^{2}$.

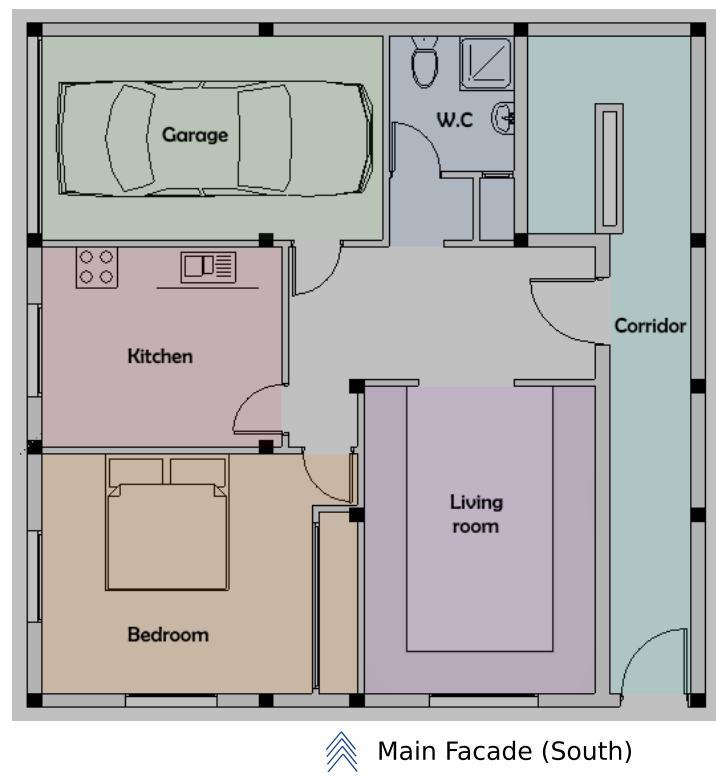

(a) Ground floor.

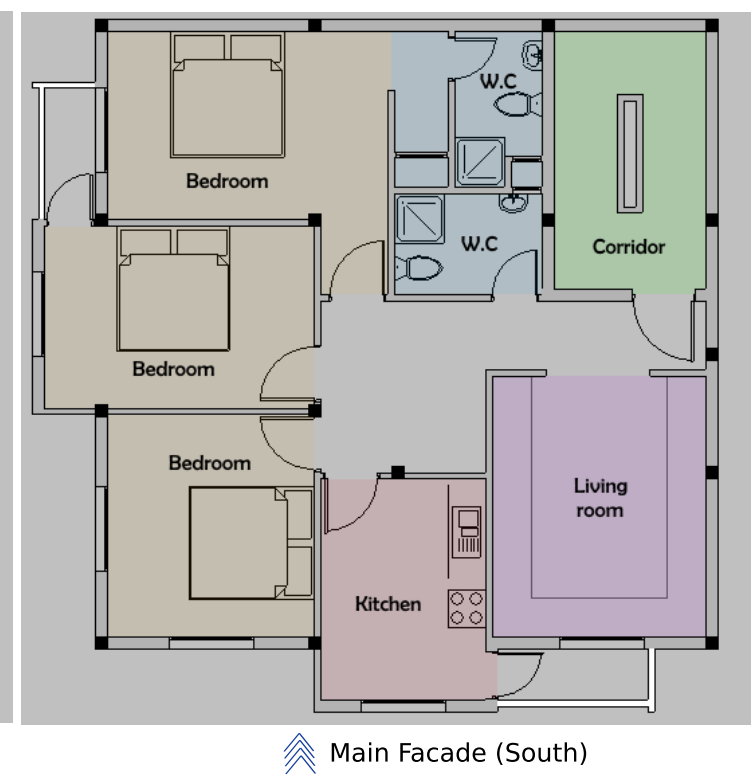

(b) First and second floor.

Figure 7. Building case study. General overview.

The initial different layers of materials were subsequently introduced according to the majority of the current Moroccan real estate and in line with the average prices based on the country's GDP. This initial configuration referred to the studied real typical residential apartments, with no passive denoted components relying on commonly used classic materials in Morocco as can be found in recent contributions $[55,56]$. The thermophysical properties and constructive characteristics of the initial building external envelope are summarized in Table 5, corresponding to Scenario 1. A 3D DesignBuilder software model was defined, as can be seen in Figure 8. Results and discussion are provided in the following sections.

Table 5. Reference residential building: initial constructive characteristics-Scenario 1.

\begin{tabular}{lccccc}
\hline & Material & $\begin{array}{c}\text { Thickness } \\
(\mathbf{m m})\end{array}$ & $\begin{array}{c}\text { Thermal Conductivity } \\
\mathbf{( W / m} \cdot \mathbf{K})\end{array}$ & $\begin{array}{c}C_{p} \\
(\mathbf{J} / \mathbf{k g} \cdot \mathbf{K})\end{array}$ & $\begin{array}{c}\text { Density } \\
\mathbf{( k g / \mathbf { m } ^ { 3 }} \mathbf{3}\end{array}$ \\
\hline & cement plaster & 15 & 0.42 & 1000 & 1800 \\
External walls & brick wall & 70 & 0.34 & 1000 & 1800 \\
$\left(1.2 \mathrm{~W} / \mathrm{m}^{2} \cdot \mathrm{K}\right)$ & air layer & 100 & 0.714 & 1012 & 1 \\
& brick wall & 70 & 0.34 & 1000 & 1800 \\
& cement plaster & 15 & 0.42 & 1000 & 1800 \\
\hline & Tile & 7 & 1.40 & 1000 & 2500 \\
Roof & mortar layer & 15 & 0.42 & 1000 & 1800 \\
$\left(1.72 \mathrm{~W} / \mathrm{m}^{2} \cdot \mathrm{K}\right)$ & reinforced concrete & 40 & 2.30 & 1000 & 2350 \\
& hollow block & 160 & 0.60 & 880 & 1000 \\
& cement plaster & 15 & 0.42 & 1000 & 1800 \\
\hline \multirow{3}{*}{ Intermediate floor } & Tile & 7 & 1.40 & 1000 & 2500 \\
& mortar layer & 15 & 0.42 & 1000 & 1800 \\
& reinforced concrete & 40 & 2.30 & 1000 & 2350 \\
\hline Glazing area & Simple glazing & \multicolumn{5}{c}{} \\
\hline
\end{tabular}




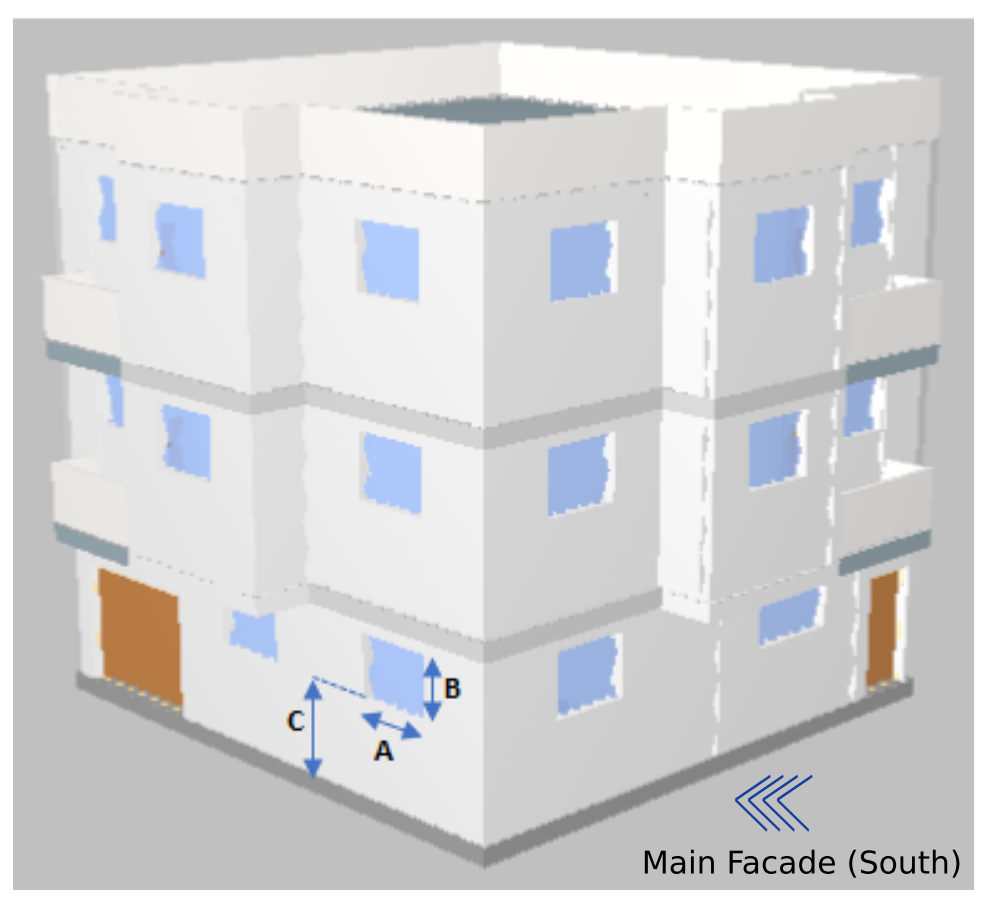

Figure 8. Case study: general overview and window dimensions $(\mathrm{A}=1.35 \mathrm{~m}, \mathrm{~B}=1.10 \mathrm{~m}, \mathrm{C}=1 \mathrm{~m})$.

\section{Results}

The simulated reference building results were analyzed and compared according to the national energy demand requirements. Table 6 firstly summarizes the results for the reference residential building located in Tangier (Morocco) with the constructive characteristics summarized in Table 5 (Scenario 1) and a total surface area of $283.4 \mathrm{~m}^{2}$. This energy consumption was based on the corresponding outdoor and indoor temperature evolution during an ordinary year for the location of Tangier (climate zone Z2, Morocco) estimated by the EnergyPlus software package (see Figure 9). Additional factors such as orientation and global irradiance, in line with another analysis focused on heating/cooling energy consumption modeling [57], were also considered. Cooling, heating and power (CHP) systems were subsequently designed and selected according to other studies, such as [58]. External temperature values were slightly different from the meteorological data given in Figure 6 due to minor software package discrepancies between Meteonorm and EnergyPlus.

From the annual cooling and heating energy consumption, and compared to the square meters of total surface $\left(283.4 \mathrm{~m}^{2}\right)$, it was then possible to estimate the annual useful energy demand corresponding to the global reference residential building: $51.90 \mathrm{kWh} / \mathrm{m}^{2}$. year. This demand exceeded the limit value established by the Moroccan RTCM regulation for the $\mathrm{Z} 2$ climate zone: $46 \mathrm{kWh} / \mathrm{m}^{2}$. year. Based on the thermal behavior and efficiency analysis provided by the DesignBuilder software package with hourly data, parameters summarized in Table 5 were then modified by introducing minimum additional thermal insulation layers in order to decrease the annual energy demand consumption. These additional layers were not compulsorily included in the Moroccan regulation, but they were necessary to meet the current national energy demand requirements. In fact, expanded (EPS) and extruded (XPS) polystyrene foam were recommended by the National Agency for the renewable energy resource and energy efficiency development (ADEREE) to be used in roof and external walls [59]. Boukhattem et al. [60] summarized the main insulation materials existing in the Moroccan market: cork, rock wool, glass wool, polyurethane, XPS, EPS and perlite. In our case example, the XPS selection was conducted according to the method of Boujnah et al. [61]; they concluded that the energy saving for XPS was higher than the EPS and polyurethane insulation materials for different Moroccan residential building case examples. Another contribution that focused on XPS is [62], where a thermal insulation analysis based on XPS for Moroccan building envelope was used as a passive technique. 
Recently, Lafqir et al. [63] claimed that $4 \mathrm{~cm}$ XPS roof's thermal insulation in different climates of Morocco reduced both heating/cooling demand by $10 \%$ and $30 \%$, respectively, compared to a noninsulated house. Consequently, by including minimum additional XPS thermal insulation layers on the roof and the external walls, the annual energy demand for Scenario 2 decreased to a value of $42.61 \mathrm{kWh} / \mathrm{m}^{2}$. year, below the limit set by the RTCM for climate zone $\mathrm{Z2}, 46 \mathrm{kWh} / \mathrm{m}^{2}$. year, $7.4 \%$ lower than the RTCM performance-based set requirement. Table 7 describes these minimum additional thermal insulation layers that were considered [64]. Figure 10 compares the results obtained for monthly energy demand, both heating and cooling energy consumption, in the Tangier location (climate zone Z2, Morocco) before considering the additional thermal insulation layers (Scenario 1) and after including them (Scenario 2).

Table 6. Heating/cooling energy demand, Tangier (Morocco)—Scenario 1.

\begin{tabular}{ccc}
\hline & $\begin{array}{c}\text { Annual Cooling/Heating } \\
\text { Energy Demand (kWh/year) }\end{array}$ & $\begin{array}{c}\text { Averaged Cooling/Heating } \\
\text { Energy Demand }\left(\mathbf{k W h} / \mathbf{m}^{2} \cdot \text { year) }\right.\end{array}$ \\
\hline Heating demand & 6632 & 23.40 \\
Cooling demand & 8077 & 28.50 \\
\hline Heating and cooling & 14,709 & 51.90 \\
\hline
\end{tabular}

Table 7. Moroccan Thermal Construction Regulation (RTCM) norms: additional thermal insulationScenario 2.

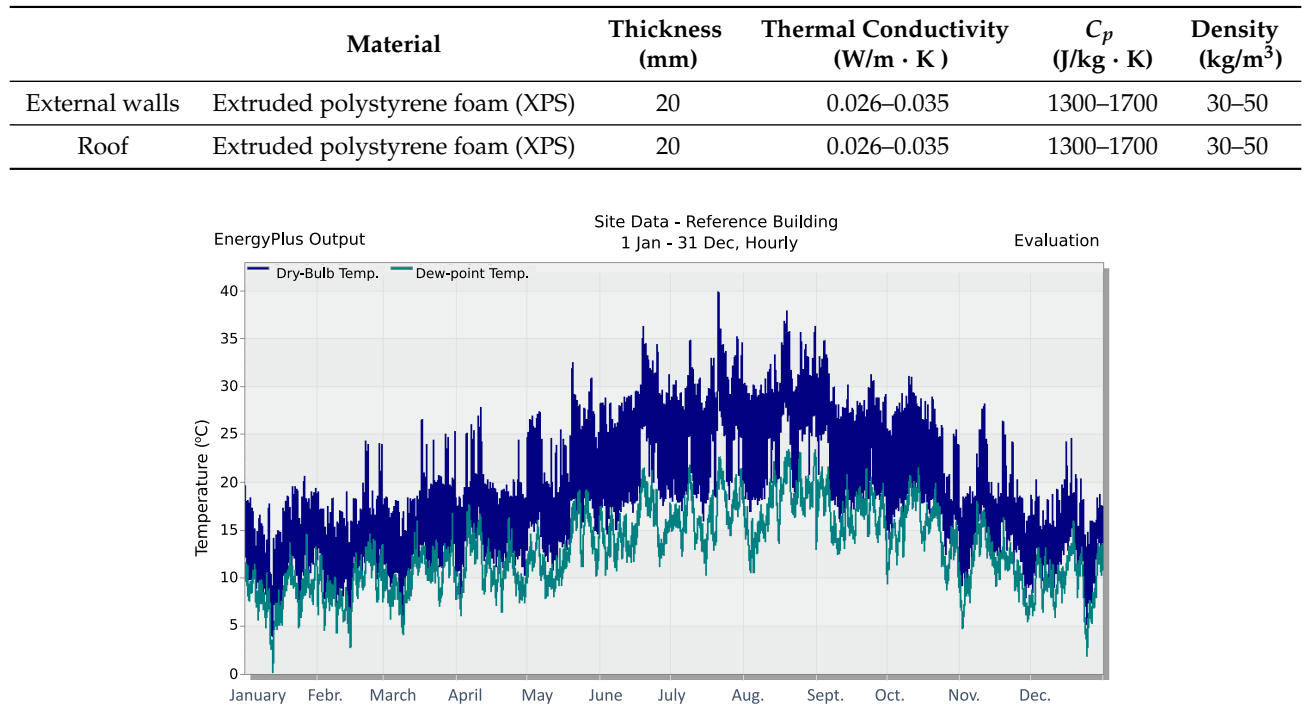

(a) Outdoor temperature evolution.

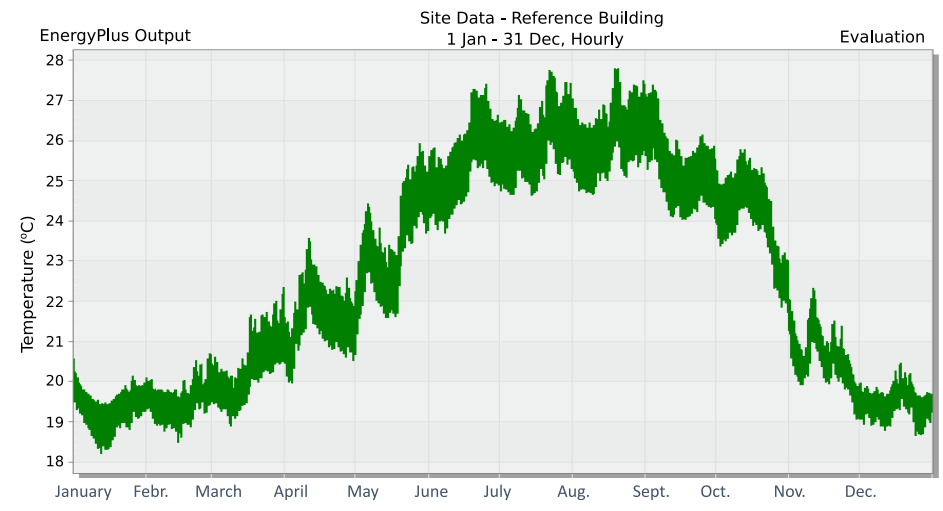

(b) Indoor temperature evolution.

Figure 9. Temperature evolution for the reference building. Tangier (Morocco)—Scenario 1. 


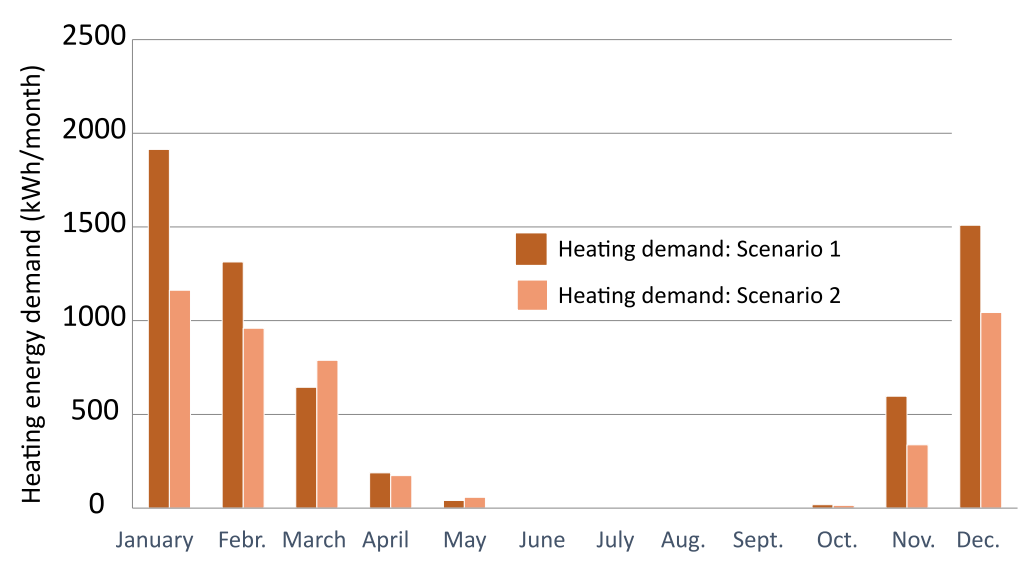

(a) Heating energy demand.

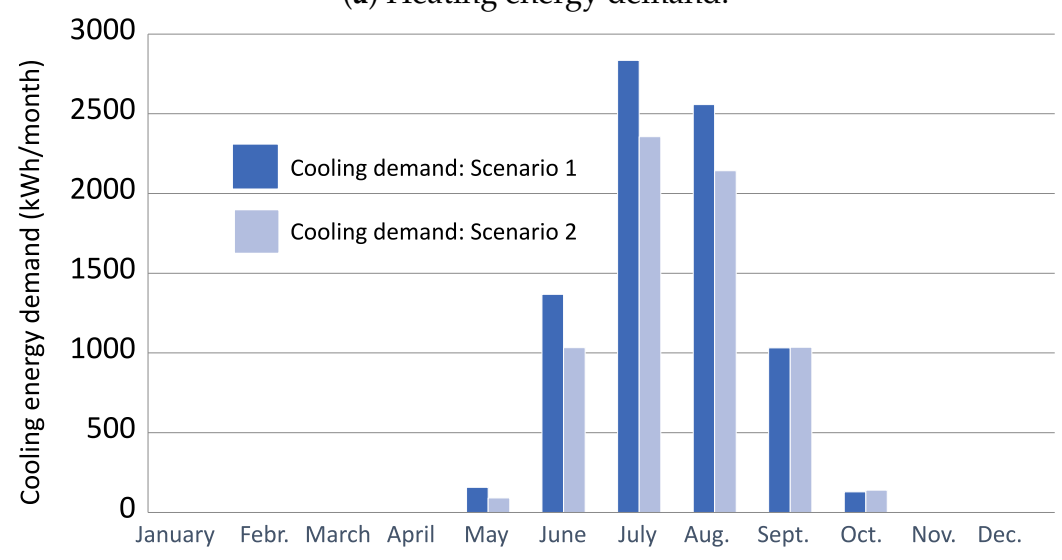

(b) Cooling energy demand.

Figure 10. Heating/cooling energy demand. Reference building in Tangier (Morocco).

Following the proposed methodology (see Figure 5), the Spanish DB-HE regulations were then applied on the reference residential building located in Tangier (Morocco), as an attempt to compare both national regulations. In this way, the latest issue of the Spanish DB-HE regulation was published in December 2019 (RD 732/2019), excluding any energy demand limit. For this reason, we considered the previous version of the national regulation (June 2017), which established energy demand limits for a building depending on the climatic zones. The reference residential building energy demand and constructive characteristics were thus initially assumed as Scenario 1, with an annual energy demand of $51.9 \mathrm{kWh} / \mathrm{m}^{2}$. year. This value is higher than the limit established by the DB-HE (version July 2017), which was $30 \mathrm{kWh} / \mathrm{m}^{2}$. year, for climate zone A3-similar to the Moroccan climate zone $\mathrm{Z2}$. As can be seen, this limit value was more demanding than the corresponding limit currently established by the Moroccan legislation for climate zone $\mathrm{z} 2-46 \mathrm{kWh} / \mathrm{m}^{2}$. year, as was previously given. Table 8 gives the minimum additional isolation layers that were considered in accordance with the Spanish requirements. Note that the minimum additional materials to meet the Spanish requirements were included, considering that the low initial cost is the primary factor in the choice of Moroccan insulation quantity [61]. With this modified reference building, Scenario 3, the total annual heating/cooling energy demand was then reduced by up to $28.70 \mathrm{kWh} / \mathrm{m}^{2}$. year, meeting the thermal energy limit established by the Spanish regulations in their previous requirement version. The monthly energy demand results for heating and cooling energy consumptions are depicted in Figure 11. The initial reference building is labeled as Scenario 1 and the improved reference residential building is labeled as Scenario 3. 
Table 8. Spanish Basic Energy Saving Requirements (DB-HE) regulation: additional thermal insulationScenario 3.

\begin{tabular}{|c|c|c|c|c|c|}
\hline & Material & $\begin{array}{l}\text { Thickness } \\
\text { (mm) }\end{array}$ & $\begin{array}{l}\text { Thermal conductivity } \\
(\mathrm{W} / \mathrm{m} \cdot \mathrm{K})\end{array}$ & $\begin{array}{c}C_{p} \\
(\mathrm{~J} / \mathrm{kg} \cdot \mathrm{K})\end{array}$ & $\begin{array}{l}\text { Density } \\
\left(\mathrm{kg} / \mathrm{m}^{3}\right)\end{array}$ \\
\hline \multirow{2}{*}{ External walls } & Extruded polystyrene foam (XPS) & 20 & $0.026-0.035$ & $1300-1700$ & $30-50$ \\
\hline & Double-glazed glass & $4-12-4$ & \multicolumn{3}{|c|}{$\mathrm{U}=2.90 \mathrm{~W} / \mathrm{m}^{2} \cdot \mathrm{K}$} \\
\hline Roof & Extruded polystyrene foam (XPS) & 20 & $0.026-0.035$ & $1300-1700$ & $30-50$ \\
\hline
\end{tabular}

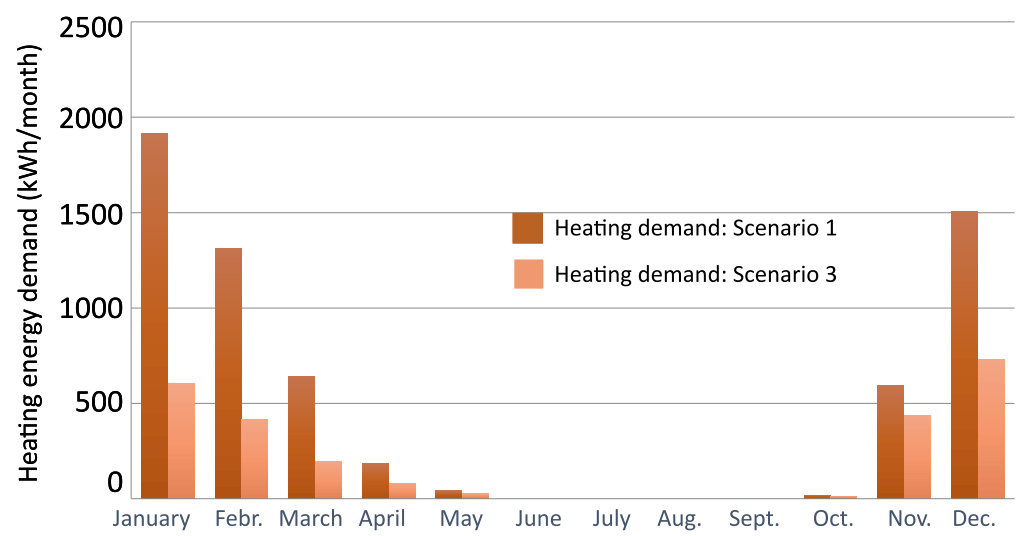

(a) Heating energy demand.

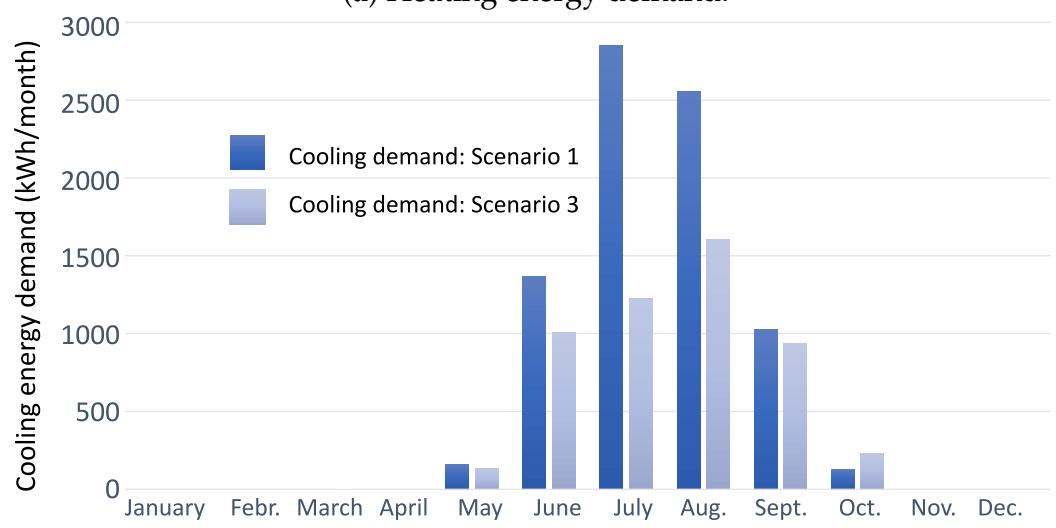

(b) Cooling energy demand.

Figure 11. Heating/cooling energy demand. Reference residential building-Scenario 3.

\section{Discussion}

According to the results obtained, and only considering energy efficiency data at the building envelope level, the Spanish regulation saves more energy than the Moroccan RTCM norms-specifically, $45.4 \%$, compared to $17.9 \%$ for the case of Morocco norms. Table 9 compares and summarizes these results. A difference in monthly energy demand for heating and cooling energy demand was then determined for the entire year between both reference residential buildings. A comparison according to the current building regulations, RTCM requirements and CTE requirements, is shown in Figure 12, where the energy demand for heating is represented by positive values and the cooling energy demand is represented by negative values. Heating and cooling energy consumption for currently typical Moroccan residential buildings were also determined and included, labeled as Scenario 1. As was previously discussed, these typical constructions demand more energy and they are not in line with the new Moroccan thermal building legislation. In fact, M'lahfi et al. affirmed that compliance with the RTCM requirements in the Morocco housing sector would allow us a final energy savings of around $22 \mathrm{kWh} / \mathrm{m}^{2}$. year and a significant $\mathrm{CO}_{2}$ reduction, depending on each climatic zone [65]. 
Table 9. Residential buildings' annual heating and cooling demands: comparison and results.

\begin{tabular}{cccc}
\hline Legislation & $\begin{array}{c}\text { Annual Heating/Cooling } \\
\text { Demand Limit }\end{array}$ & \multicolumn{2}{c}{ Reference Residential Building } \\
& Initial Design (Scenario 1) & Final Design \\
\hline Morocco RTCM (November 2015) & $46 \mathrm{kWh} / \mathrm{m}^{2} \cdot$ year & $51.9 \mathrm{kWh} / \mathrm{m}^{2} \cdot$ year & $42.61 \mathrm{kWh} / \mathrm{m}^{2} \cdot$ year $(-17.9 \%, \mathrm{Scenario} 2)$ \\
\hline Spain DB-HE (June 2017) & $30 \mathrm{kWh} / \mathrm{m}^{2} \cdot$ year & $51.9 \mathrm{kWh} / \mathrm{m}^{2} \cdot$ year & $28.7 \mathrm{kWh} / \mathrm{m}^{2} \cdot$ year $(-45.4 \%, \mathrm{Scenario} 3)$ \\
\hline
\end{tabular}

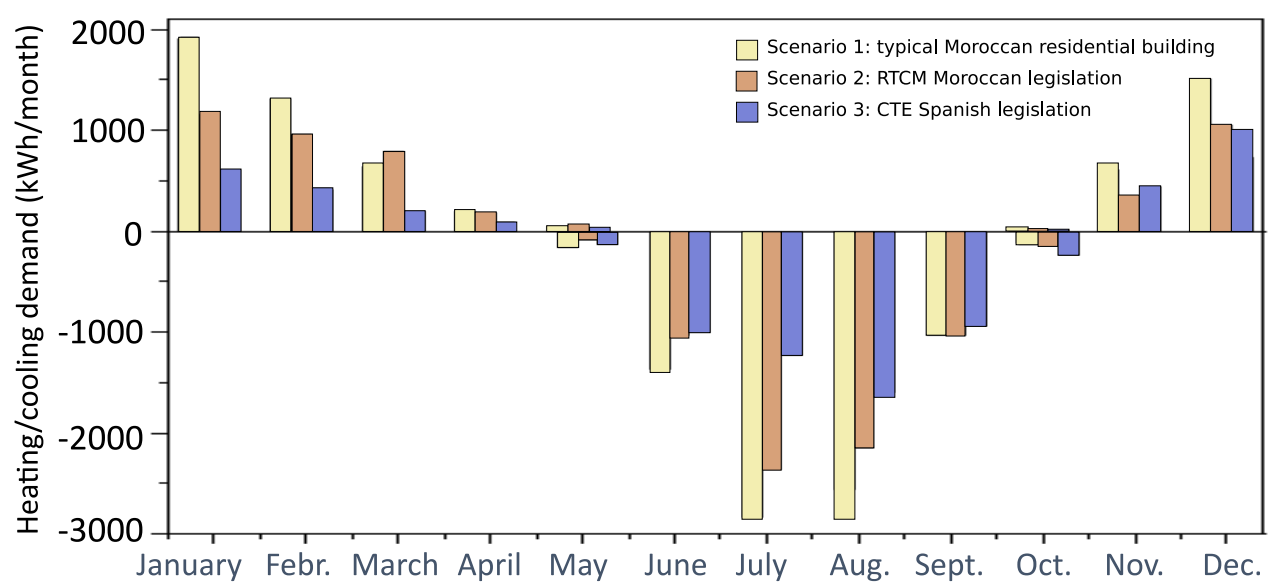

Figure 12. Monthly heating and cooling energy demands: comparison of scenarios.

The Spanish DB-HE regulation also includes the requirements of the RITE. A building with almost zero energy consumption was then finally obtained. In this context, the role of the zero-energy building (ZEB) can then be established as the standard reference for the expected achievements in terms of balancing the needs and the self-sufficiency of a building in serviceable conditions [66]. Moreover, other countries, such as Denmark, are promoting even more strict legislation, with establishment of residential buildings' annual heating and cooling demands below $20 \mathrm{kWh} /\left(\mathrm{m}^{2}\right.$. year) after 2020 [67], in a similar way to current passive house data $\left(15 \mathrm{kWh} / \mathrm{m}^{2}\right.$. year) [68]. Therefore, this Spanish regulation currently constitutes a basic regulatory instrument for energy efficiency and safety requirements for thermal installations in buildings. Air conditioning, heating, ventilation (HVAC) and production of sanitary hot water (DHW), aimed at meeting the demand for people's well-being and hygiene as well as the contribution of renewable energies to cover energy demand, are then considered as fixed installations [69]. For the Morocco case example, the only requirement that Moroccan legislation currently describes in terms of energy efficiency in buildings is the limit of energy demand for heating and air conditioning needs by climatic zones according to the RTCM. This regulation is also linked to the MEPS standard for air conditioning requirements, establishing minimum energy efficiency standards for air conditioners and refrigerators.

\section{Conclusions}

A reference residential building was considered for a simulation to compare Morocco and Spain thermal building performance and energy demand under both national current regulations. Tangier (Morocco) location was selected as the case example, presenting similar meteorological conditions in comparison to southern Spain. The DesignBuilder software package was selected to estimate heating and cooling energy demand. Typical Moroccan constructive materials-mainly based on cement, mortar layer and simple glazing - were initially considered for preliminary building design. Additional isolation improvements were then proposed to meet the corresponding national requirements by minimizing such isolation layers. According to the results, the energy demand reduction obtained with the Moroccan RCTM application in climate zone Z2 (Tangier) was 17.9\%, compared to $45.4 \%$ with the DB-HE Spanish application by considering the same meteorological conditions corresponding to climate zone A3 (Algeciras, South of Spain). These results were based on 
the constructive design parameters to obtain thermal comfort for the users of the buildings meeting the energy demand requirements. They are in line with insulation materials currently available in Morocco as well as the Moroccan standard living. By considering the annual energy demands under the different case example scenarios, it is then necessary to modify the current Moroccan RTCM norms with the aim of achieving $20 \%$ energy savings by the 2030 horizon. In fact, the annual energy demand limits should be reduced as a solution to meet such 2030 requirements, which are not achievable according to the results (Scenario 2). These modifications should be in line with nearby countries, such as Spain, including the promotion of renewables through incentives.

As future lines of research, the authors are expanding their analysis through a zero energy consumption building scenario in Morocco, which is currently included in most of European building design and recommendation roadmaps. In addition, the authors are currently analysing the Moroccan climatic zoning which are mainly based on administrative limits, with the aim of proposing an alternative climatic zone characterization by considering a variety of meteorological variables.

Author Contributions: Conceptualization, A.M.-G. and M.A.; methodology, M.S.-G.C.; software, I.M.; validation, I.M. and M.M.; formal analysis, M.S.-G.C.; investigation, I.M.; resources, M.M. and M.A.; data curation, I.M. and M.A.; writing-original draft preparation, I.M.; writing-review and editing, A.M.-G. and M.S.-G.C.; supervision, A.M.-G. All authors have read and agreed to the published version of the manuscript.

Funding: This research received no external funding.

Conflicts of Interest: The authors declare no conflict of interest.

\section{Abbreviations}

The following abbreviations are used in this manuscript:

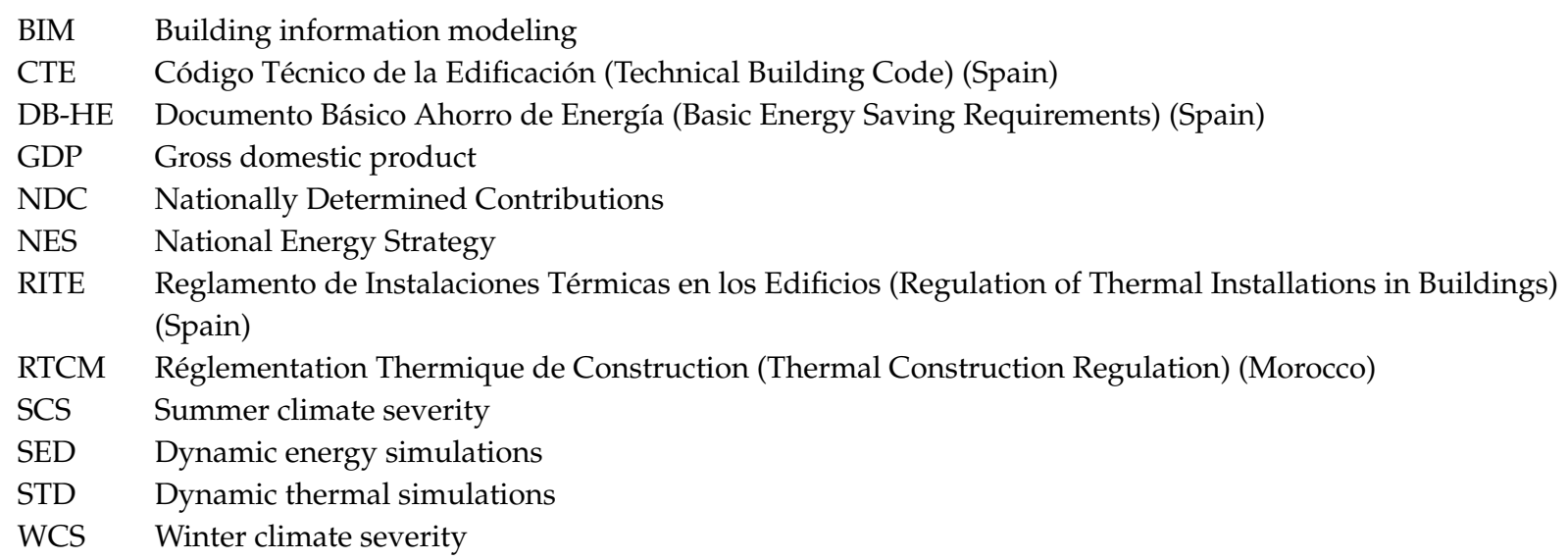

\section{References}

1. Mugnier, D. 2019 Annual Report-Feature Article on Solar Integrated Building Facades; Technical Report; IEA Solar Heating and Cooling Programme: Santiago, Chile, 2019.

2. Peci-López, F; Ruiz de Adana Santiago, M. Sensitivity study of an opaque ventilated façade in the winter season in different climate zones in Spain. Renew. Energy 2015, 75, 524-533. [CrossRef]

3. Global Status Report for Buildings and Construction 2019. Technical Report. International Energy Agency. Available online: https: / / www.iea.org/reports/global-status-report-for-buildings-and-construction-2019 (accessed on 25 September 2020).

4. Kyprianou, I.; Serghides, D.; Varo, A.; Gouveia, J.; Kopeva, D.; Murauskaite, L. Energy poverty policies and measures in 5 EU countries: A comparative study. Energy Build. 2019, 196, 46-60. [CrossRef]

5. Kephalopoulos, S.; Geiss, O.; Barrero-Moreno, J.; D'Agostino, D.; Paci, D. Promoting Healthy and Highly Energy Performing Buildings in the European Union: National Implementation of Related Requirements of the Energy Performance Buildings Directive (2010/31/EU); Technical Report, Science for Policy report 978-92-79-70594-6; Joint Research Centre: Luxemburg, 2017. 
6. Mercader-Moyano, P.; Esquivias, P.M.; Muntean, R. Eco-Efficient Analysis of a Refurbishment Proposal for a Social Housing. Sustainability 2020, 12. [CrossRef]

7. Kousksou, T.; Allouhi, A.; Belattar, M.; Jamil, A.; El Rhafiki, T.; Zeraouli, Y. Morocco's strategy for energy security and low-carbon growth. Energy 2015, 84, 98-105. [CrossRef]

8. López, R.C.; García-Álvarez-Coque, J.M.; Azcárate, T.G. EU Mediterranean Relations in the Field of Agriculture. 2013. Available online: www.institutdelors.eu/wp-content/uploads/2018/01/mediterraneanagriculturelopezgarciagarcia-ne-jdi-apr13.pdf (accessed on 25 September 2020).

9. Jawad, R.; Aboushady, N.; Mansour, H.A.; Coutts, A.; Bencheikh, N.; Lupieri, S. New Directions in Social Policy in MENA Region. 2018. Available online: https://www.unrisd.org/unrisd/website/ document.nsf/(httpPublications)/3A22EDA67CBDF1E7C1258386004F42D0?OpenDocument (accessed on 16 November 2020).

10. Chauffour, J.P. Morocco 2040: Emerging by Investing in Intangible Capital; The World Bank: Washington, DC, USA, 2017.

11. Benkassmi, M.; Abdelkhalek, T. Building Human Capital: Lessons from Country Experiences-Morocco; World Bank: Washington, DC, USA, 2020.

12. Ching, L. Towards the Transformation of Our Agricultural and Food systems. (SDG 2 End Hunger, Achieve Food Security and Improved Nutrition and Promote Sustainable Agriculture). Spotlight on Sustainable Development. Report by the Reflection Group on the 2030 Agenda for Sustainable Development. 2016; Volume 192, pp. 33-38. Available online: https://www.reflectiongroup.org/en/node/604 (accessed on 25 September 2020).

13. Muchhala, B. Report by the Reflection Group on the 2030 Agenda for Sustainable Development. Spotlight Sustain. Dev. 2016, 2016, 73.

14. Hamdaoui, S.; Mahdaoui, M.; Allouhi, A.; El Alaiji, R.; Kousksou, T.; El Bouardi, A. Energy demand and environmental impact of various construction scenarios of an office building in Morocco. J. Clean. Prod. 2018, 188, 113-124. [CrossRef]

15. Energy Policies Beyond IEA Countries: Morocco 2019; Technical Report; International Energy Agency: Paris, France, 2019. Available online: https: / /www.iea.org/reports/energy-policies-beyond-iea-countriesmorocco-2019 (accessed on 25 September 2020).

16. Note de Conjoncture Énergétique (In French); Technical report; Government of Morocco: Rabat, Morocco, 2019. Available online: https://https://www.mem.gov.ma/en/pages/rapports.aspx (accessed on 25 September 2020).

17. Energy Policies Beyond IEA Countries; Technical Report; International Energy Agency: Paris, France, 2019. Available online: https:/ / www.mem.gov.ma/Lists/Lst_rapports/Attachments/14/IDR_Morocco_ES_FRE. pdf (accessed on 25 September 2020). (In French)

18. Arriba-Segurado, P.; García-Barquero, C. Energy Efficiency Trends and Policies in Spain: A Decision Support Tool for Energy Efficiency Policy Evaluation; Technical Report; Spanish Ministry of Industry, Energy and Tourism: Madrid, Spain, 2018. Available online: https://www.odyssee-mure.eu/publications/national-reports/ energy-efficiency-spain.pdf (accessed on 25 September 2020).

19. Alami Merrouni, A.; Mezrhab, A.; Mezrhab, A. PV sites suitability analysis in the Eastern region of Morocco. Sustain. Energy Technol. Assess. 2016, 18, 6-15. [CrossRef]

20. Touili, S.; Alami Merrouni, A.; El Hassouani, Y.; illah Amrani, A.; Rachidi, S. Analysis of the yield and production cost of large-scale electrolytic hydrogen from different solar technologies and under several Moroccan climate zones. Int. J. Hydrog. Energy 2020. [CrossRef]

21. Ezzine, H.; Bouziane, A.; Ouazar, D. Seasonal comparisons of meteorological and agricultural drought indices in Morocco using open short time-series data. Int. J. Appl. Earth Obs. Geoinf. 2014, 26, 36-48. [CrossRef]

22. Choukri, K.; Naddami, A.; Hayani, S. Renewable energy in emergent countries: Lessons from energy transition in Morocco. Energy, Sustain. Soc. 2017, 7. [CrossRef]

23. Alhamwi, A.; Kleinhans, D.; Weitemeyer, S.; Vogt, T. Moroccan National Energy Strategy reviewed from a meteorological perspective. Energy Strategy Rev. 2015, 6, 39-47. [CrossRef] 
24. Harrouni, K.E.; Filali, M.; Kharmich, H.; Mansour, M.; Laaroussi, N.; Garoum, M. Energy Efficient Houses Meeting both Bioclimatic Architecture Principles and Moroccan Thermal Regulation. In Proceedings of the 6th International Renewable and Sustainable Energy Conference (IRSEC), Tanger, Morocco, 5-8 December 2018; pp. 1-8.

25. Merini, I.; Molina-García, A.; García-Cascales, M.S.; Ahachad, M. Energy Efficiency Regulation and Requirements: Comparison Between Morocco and Spain. In Advanced Intelligent Systems for Sustainable Development (AI2SD'2018); Ezziyyani, M., Ed.; Springer International Publishing: Cham, Switzerland, 2019; pp. 197-209.

26. Morocco Renewable Energy Target 2030; Technical report; International Energy Agency: Paris, France, 2019. Available online: https:/ / www.iea.org/policies/6557-morocco-renewable-energy-target-2030 (accessed on 25 September 2020)

27. Partner Country Series-Clean Energy Technology Assessment Methodology Pilot Study: Morocco; Technical Report; International Energy Agency: Paris, France, 2016. Available online: https:/ / https:/ /www.iea.org/reports/ partner-country-series-clean-energy-technology-assessment-methodology-pilot-study-morocco (accessed on 25 September 2020).

28. Gifreu Font, J. La integración de medidas de eficiencia energética en el sector de la edificación en España a la vista de los objetivos de la UE para los horizontes 2020-2030. El district heating and cooling (In Spanish). Rev. Catalana Dret Ambient 2018, 10. [CrossRef]

29. Tolón-Becerra, A.; Lastra-Bravo, X.B.; Fernández-Membrive, V.J.; Flores-Parra, I. Opportunities in Spanish Energy Efficiency. Current Situation, Trends and Potential in the Building Sector. Energy Procedia 2013, 42, 63-72. [CrossRef]

30. Comisión de Expertos de Transición Energética; Technical Report; Government of Spain: Madrid, Spain, 2018. Available online: http:/ / www6.mityc.es/aplicaciones/transicionenergetica/informe_cexpertos_20180402_ veditado.pdf (accessed on 25 September 2020). (In Spanish)

31. López-Ochoa, L.M.; Bobadilla-Martínez, D.; Las-Heras-Casas, J.; López-González, L.M. Towards nearly zero-energy educational buildings with the implementation of the Energy Performance of Buildings Directive via energy rehabilitation in cold Mediterranean zones: The case of Spain. Energy Rep. 2019, 5, 1488-1508. [CrossRef]

32. Arrué, P.; Romero, A.M.; Cárcel, A.C. Comparative Analysis of Calculation of Buildings Drainage Systems. In Project Management and Engineering; Ayuso Muñoz, J.L., Yagüe Blanco, J.L., Capuz-Rizo, S.F., Eds.; Springer International Publishing: Cham, Switzerland, 2015; pp. 87-103.

33. Blázquez, T.; Ferrari, S.; Suárez, R.; Sendra, J.J. Adaptive approach-based assessment of a heritage residential complex in southern Spain for improving comfort and energy efficiency through passive strategies: A study based on a monitored flat. Energy 2019, 181, 504-520. [CrossRef]

34. Saheb, Y. Modernising building energy codes to secure our global energy future. IEA Policy Pathw. Ser. 2011. Available online: https://unfccc.int/files/documentation/submissions_and_statements/application/ pdf/international_energy_agency_-_unep._modernising_building_energy_codes_to_secure_our_global_ energy_future_-_submitted_by_the_u.s.pdf (accessed on 25 September 2020).

35. Xiong, J.; Yao, R.; Grimmond, S.; Zhang, Q.; Li, B. A hierarchical climatic zoning method for energy efficient building design applied in the region with diverse climate characteristics. Energy Build. 2019, 186, 355-367. [CrossRef]

36. Fellak, I.; El Ganaoui, M.; Mimet, A.; Maalouf, A. The solar domestic water heating system in the six Moroccan climate zones. Energy Procedia 2017, 139, 180-185. Materials \& Energy I (2015). [CrossRef]

37. Reglement Thermique de Construction au Maroc; Technical Report; Moroccan Agency For Energy Efficiency. 2015. Available online: https://www.amee.ma/sites/default/files/inline-files/Reglement_thermique_de_ construction_au_Maroc.pdf (accessed on 25 September 2020). (In French)

38. Walsh, A.; Cóstola, D.; Labaki, L.C. Comparison of three climatic zoning methodologies for building energy efficiency applications. Energy Build. 2017, 146, 111-121. [CrossRef]

39. Kottek, M.; Grieser, J.; Beck, C.; Rudolf, B.; Rubel, F. World map of the Köppen-Geiger climate classification updated. Meteorol. Z. 2006, 15, 259-263. [CrossRef]

40. Martín, F.D.C.; Valiente, E.E.; D’Amico, F. Zonificación climática para su aplicación al diseño bioclimático. Aplicación en Galicia (España). Inf. Constr. 2017, 69, 218. (In Spanish) [CrossRef] 
41. Gangolells, M.; Casals, M.; Forcada, N.; Macarulla, M.; Cuerva, E. Energy mapping of existing building stock in Spain. J. Clean. Prod. 2016, 112, 3895-3904. [CrossRef]

42. Huertas, J.D. Analysis of the Relationship of the Improvement of Façades and Thermal Bridges of Spanish Building Stock with the Mitigation of its Energy and Environmental Impact. Energies 2020, 13, 4499. [CrossRef]

43. Remund, J.; Müller, S.C. Solar radiation and uncertainty information of Meteonorm 7. In Proceedings of the 26th European Photovoltaic Solar Energy Conference and Exhibition, Hamburg, Germany, 5-8 September 2011; pp. 4388-4390.

44. Meteonorm. A Software Program for Meteorological Parameters Around the World. Technical Report. Available online: https:/ / meteonorm.com/en/ (accessed on 25 September 2020)

45. Walsh, A.; Cóstola, D.; Labaki, L.C. Review of methods for climatic zoning for building energy efficiency programs. Build. Environ. 2017, 112, 337-350. [CrossRef]

46. Bouhal, T.; ed Din Fertahi, S.; Agrouaz, Y.; El Rhafiki, T.; Kousksou, T.; Zeraouli, Y.; Jamil, A. Technical assessment, economic viability and investment risk analysis of solar heating/cooling systems in residential buildings in Morocco. Sol. Energy 2018, 170, 1043-1062. [CrossRef]

47. Daemei, A.B.; Limaki, A.K.; Safari, H. Opening Performance Simulation in Natural Ventilation Using Design Builder (Case Study: A Residential Home in Rasht). Energy Procedia 2016, 100, 412-422. [CrossRef]

48. Ascione, F.; Bianco, N.; Mauro, G.M.; Napolitano, D.F. Retrofit of villas on Mediterranean coastlines: Pareto optimization with a view to energy-efficiency and cost-effectiveness. Appl. Energy 2019, 254, 113705. [CrossRef]

49. Ahmad, A.; Kumar, A.; Prakash, O.; Aman, A. Daylight availability assessment and the application of energy simulation software-A literature review. Mater. Sci. Energy Technol. 2020, 3, 679-689. [CrossRef]

50. Crawley, D.B.; Lawrie, L.K.; Winkelmann, F.C.; Buhl, W.; Huang, Y.; Pedersen, C.O.; Strand, R.K.; Liesen, R.J.; Fisher, D.E.; Witte, M.J.; et al. EnergyPlus: Creating a new-generation building energy simulation program. Energy Build. 2001, 33, 319-331. Special Issue: BUILDING SIMULATION'99. [CrossRef]

51. Kim, D.W.; Park, C.S. Difficulties and limitations in performance simulation of a double skin façade with EnergyPlus. Energy Build. 2011, 43, 3635-3645. [CrossRef]

52. De Rosa, M.; Bianco, V.; Scarpa, F.; Tagliafico, L.A. Heating and cooling building energy demand evaluation; a simplified model and a modified degree days approach. Appl. Energy 2014, 128, 217-229. [CrossRef]

53. National Agency for the Development of Renewable Energy and energy Efficiency (ADEREE) in Morocco. Règlement Thermique de Construction au Maroc, Simplified Version. Available online: http:/ / architectesmeknestafilalet.ma/documentation_telechargements / (accessed on 25 September 2020). (In French)

54. Fernández-Antolín, M.M.; del Río, J.M.; González-Lezcano, R.A. Influence of Solar Reflectance and Renewable Energies on Residential Heating and Cooling Demand in Sustainable Architecture: A Case Study in Different Climate Zones in Spain Considering Their Urban Contexts. Sustainability 2019, 11, 6782. [CrossRef]

55. Mastouri, H.; Bahi, H.; Radoine, H.; Benhamou, B. Thermal performance and adherence of local materials to the Moroccan Building Code requirements. In Proceedings of the 2020 5th International Conference on Renewable Energies for Developing Countries (REDEC), Marrakech, Morocco, 24-26 March 2020; pp. 1-5. [CrossRef]

56. Chegari, B.; Tabaa, M.; Moutaouakkil, F.; Simeu, E.; Medromi, H. Energy Savings and Thermal Comfort Benefits of Shading Devices: Case Study of a Typical Moroccan Building. In Proceedings of the 4th International Conference on Smart City Applications, Casablanca, Morocco, 2-4 October 2019; Association for Computing Machinery: New York, NY, USA, 2019; Number 63 in SCA '19, p. 8. [CrossRef]

57. Al-Homoud, M.S. Computer-aided building energy analysis techniques. Build. Environ. 2001, 36, 421-433. [CrossRef]

58. Fumo, N.; Mago, P.J.; Chamra, L.M. Analysis of cooling, heating, and power systems based on site energy consumption. Appl. Energy 2009, 86, 928-932. [CrossRef]

59. National Agency for the Development of Renewable Energy and energy Efficiency (ADEREE) in Morocco. Guide Technique sur l'isolation thermique du bâtiment au Maroc. Available online: https://www. amee.ma/sites/default/files/inline-files/Guide_Technique_de_IIsolation_Thermique_0.pdf (accessed on 25 September 2020). (In French) 
60. Boukhattem, L.; Boumhaout, M.; Hamdi, H.; Benhamou, B.; Ait Nouh, F. Moisture content influence on the thermal conductivity of insulating building materials made from date palm fibers mesh. Constr. Build. Mater. 2017, 148, 811-823. [CrossRef]

61. Boujnah, M.; Jraida, K.; Mounir, I. Determination of Optimal Roof Insulation Thickness in Residential Building in Marrakech. In Proceedings of the 2017 International Renewable and Sustainable Energy Conference (IRSEC), Tangier, Morocco, 4-7 December 2017; pp. 1-4. [CrossRef]

62. Ouhaibi, S.; Gounni, A.; Belouaggadia, N.; Ezzine, M.; Lbibb, R. Thermal performance of new ecological material integrated into residential building in semi-arid and cold climates. Appl. Therm. Eng. 2020, 181, 115933. [CrossRef]

63. Lafqir, F.E.; Sobhy, I.; Benhamou, B.; Bennouna, A.; Limam, K. Thermal performance of passive techniques integrated to a house and the concept of passive house in the six climates of Morocco. Sci. Technol. Built Environ. 2020, 26, 1490-1508. [CrossRef]

64. Zou, N. Thermal Insulation Materials for Wall and Roof; Chemistry and Industry Public House: Beijing, China, 2008.

65. M'lahfi, B.; Amegouz, D.; El Qandil, M. A new approach for the mandatory application of the thermal regulation of construction (RTCM) in the future moroccan buildings. Appl. Sci. 2020, 2, 1656. [CrossRef]

66. Belussi, L.; Barozzi, B.; Bellazzi, A.; Danza, L.; Devitofrancesco, A.; Fanciulli, C.; Ghellere, M.; Guazzi, G.; Meroni, I.; Salamone, F.; et al. A review of performance of zero energy buildings and energy efficiency solutions. J. Build. Eng. 2019, 25, 100772. [CrossRef]

67. Liu, Z.; Liu, Y.; He, B.J.; Xu, W.; Jin, G.; Zhang, X. Application and suitability analysis of the key technologies in nearly zero energy buildings in China. Renew. Sustain. Energy Rev. 2019, 101, 329-345. [CrossRef]

68. Schnieders, J.; Feist, W.; Rongen, L. Passive Houses for different climate zones. Energy Build. 2015, 105, 71-87. [CrossRef]

69. Mata, E.; Korpal, A.K.; Cheng, S.H.; Navarro, J.J.; Filippidou, F.; Reyna, J.L.; Wang, R. A map of roadmaps for zero and low energy and carbon buildings worldwide. Environ. Res. Lett. 2020. [CrossRef]

(C) 2020 by the authors. Licensee MDPI, Basel, Switzerland. This article is an open access article distributed under the terms and conditions of the Creative Commons Attribution (CC BY) license (http://creativecommons.org/licenses/by/4.0/). 